Karolina Wykrzykowska

https://doi.org/10.26881/pwe.2020.50.11

ORCID: 0000-0001-5252-2319

Uniwersytet Gdański

karolina.zyra272@o2.pl

\title{
Wykorzystanie eksperymentu jako wprowadzenia w temat zajęć w przedszkolu
}

\section{Summary}

\section{Using experiment as an introduction to a topic in preschool}

This article is a description of experiences gained during two lessons where experiments were used as a way of introducing the students to a topic in a group of 6-year-olds. Experiments were also used to create a space for students' inquiry. Constructivism and autoevaluation were used as a theoretical base of the analysis. The conclusions of the investigation not only prove that experiments are a more effective way of getting the children interested in a lesson, but also play an important role in developing students' research skills and their curiosity.

Keywords: experiments, preschool education, constructivism, research skills

Słowa kluczowe: eksperymenty, edukacja przedszkolna, konstruktywizm, umiejętności badawcze

\section{Wstęp}

Obecnie w obszarze edukacji zachodzą dynamiczne zmiany, których celem jest zmiana procesu kształcenia tak, aby w jego centrum znajdował się uczeń i jego potrzeby. Indywidualizacja kształcenia stawia przed nauczycielem nowe wyzwania, które wymagają od niego poszukiwania alternatywnych rozwiązań. Może on wybierać z szerokiej gamy metod aktywizujących, które pozwolą uczniom na wykorzystanie ich potencjału.

Zgodnie z nową podstawą programową edukacja w przedszkolu ma na celu wspieranie całościowego rozwoju dzieci poprzez stwarzanie im warunków do odkrywania własnych możliwości oraz gromadzenia doświadczeń. Ponadto do jednych z głównych zadań nauczyciela należy pomoc w samodzielnym badaniu świata przez dzieci i w dobieraniu treści do ich poziomu rozwoju oraz respektowanie ich indywidualnych potrzeb i zainteresowań. Wsparcie udzielane dzieciom w przedszkolu powinno skutkować osiągnięciem przez nie dojrzałości do podjęcia nauki na pierwszym etapie edukacji. Wymaga to od nauczyciela stworzenia warunków, które pozwolą jego wychowankom na swobodną eksplorację różnych zjawisk tak, aby mogli oni poznawać świat, a przy tym także swoje możliwości i zainteresowania. 
Artykuł ten jest powiązany z dwoma rodzajami celów. Z jednej strony ma on charakter praktyczny, ponieważ jako nauczyciel inicjowałam działania w swojej klasie zmierzające do urozmaicenia praktyki i głębszego zaangażowania uczniów w proces uczenia się. Z drugiej zaś można wskazać cel teoretyczny, gdyż nadal jest zbyt mało badań o czynnościach badawczych dzieci podejmowanych w realnych sytuacjach edukacyjnych. W tym zakresie zauważalna jest przewaga analiz psychologicznych nad pedagogicznymi, w których uwzględnia się kontekst typowy dla codziennego funkcjonowania dzieci w placówkach.

\section{Przesłanki teoretyczne i metodologiczne}

$\mathrm{Na}$ etapie edukacji przedszkolnej kształcenie powinno się skupiać na odkrywaniu przez dzieci ich potencjału oraz swobodnej eksploracji otaczającego świata. Ważne jest, aby w tym procesie to uczeń odgrywał aktywną rolę, a nauczyciel jedynie wskazywał mu drogę oraz zapewniał odpowiednie wsparcie. Szczególny nacisk położono na to w konstruktywizmie, którego prekursorami byli Jean Piaget (1966), Lew Wygotski (1978) oraz Jerome Bruner (1978). Konstruktywizm współcześnie przyjmuje rozmaite formy, które łączy założenie, że wiedza o świecie (naukowa i potoczna) wymaga interakcji społecznych, aby mogła zostać skonstruowana (Wendland 2011).

Pomimo pojawiania się nowych teorii dotyczących edukacji konstruktywizm nadal pozostaje przedmiotem zainteresowania wielu badaczy. Bartosz Atroszko (2018) opisuje go jako źródło inspiracji dla doskonalenia procesu kształcenia nauczycieli. Według autora konstruktywizm zwraca szczególną uwagę na zaangażowanie podmiotu, sprzyja twórczości, akcentuje relacje między językiem a myśleniem, charakteryzuje się większą tolerancją w interakcjach międzyludzkich, jest bardziej otwarty na dialog, a także docenia wartość wiedzy potocznej. Elżbieta Marek (2015) bada konstruktywizm w kontekście indywidualizacji pracy nauczyciela z uczniami, poddając analizie wybrane programy edukacji wczesnoszkolnej. Natomiast Edgar Jenkins (2000) analizuje w swoich badaniach zastosowanie konstruktywistycznej teorii nauczania w edukacji przyrodniczej. Autor stara się także odpowiedzieć na pytanie o to, czy konstruktywizm jest wpływowym modelem czy też najbardziej niebezpieczną tendencją intelektualną. Równie ważnymi kwestiami zajmuje się Manuel Bächtold (2013). Badacz poszukuje odpowiedzi na pytanie: Co dokładnie uczniowie konstruują? Autor dowodzi, że ze względu na zróżnicowany charakter konstruktywizmu istnieje wiele odpowiedzi na to pytanie. Odpowiedzi te się uzupełniają, ponieważ dotyczą różnych aspektów procesu nauczania i uczenia się.

Do najważniejszych polskich badaczy zajmujących się konstruktywizmem należą: Dorota Klus-Stańska, Ewa Filipiak, Bogusława Gołębniak, Stanisław Dylak, Renata Michalak, Józefa Bałachowicz. Klus-Stańska w swoich badaniach szczególną uwagę poświęca roli wiedzy osobistej. Według autorki wiedza jest tworem o charakterze społecznym i równocześnie indywidualnym konstruktem myślowym (Klus-Stańska 2000). Wiedza osobista określana jest także mianem wiedzy potocznej. Najprościej można ją zdefiniować jako wiedzę, która jest wykorzystywana na co dzień (Szydłowski 1991). 
Henryk Szydłowski zwraca również uwagę na to, że wiedza potoczna jest podstawowa, trwała oraz najbardziej powszechna. Jednak ze względu na swój nienaukowy charakter występuje w niej wiele błędów, co może negatywnie wpłynąć na jakość nauczania. Należy mieć także na uwadze, że na wiedzę osobistą składają się konstrukty myślowe jednostki, które bazują na doświadczeniach, a to oznacza, że są jedynie interpretacją rzeczywistości (Rybska 2017). Eliza Rybska podkreśla również, że w umyśle wiedza naukowa oraz potoczna są od siebie zależne. Według Klus-Stańskiej (2000, 2010) konstruktywiści skupiają swoją uwagę właśnie na wiedzy osobistej uczniów oraz ich kompetencjach, ponieważ są one punktem wyjścia uczenia się. Zapewnia to bowiem swobodną integrację wiedzy potocznej z nowymi informacjami i pojęciami. Eliza Rybska (2017) zauważa, że każdy z nas jest osadzony w potoczności, co wiąże się z naturą naszego myślenia i kulturą, w jakiej dorastaliśmy. Fakt ten wpływa na nasz światopogląd i sprawia, że wszyscy bez względu na zdobyte wykształcenie posiadamy zarówno pojęcia naukowe, jak i potoczne.

Do przekształcania wiedzy osobistej w wiedzę publiczną, naukową niezbędne jest zapewnienie uczącym się edukacyjnego rusztowania (scaffolding), którego rolę podkreśla się w konstruktywizmie socjo-kulturowym. Zakłada się w nim bowiem, że zarówno rozwój umysłowy, jak i uczenie się zachodzą w interakcji między jednostką a kulturą. Twierdzi się również, że każdą z wyższych funkcji psychicznych dziecka można w jego rozwoju odnaleźć dwukrotnie: jako działalność społeczną (inaczej zwaną funkcją interpsychiczną) oraz jako działalność indywidualną (funkcja intrapsychiczna) (Wygotski 1971). Co ważne, aby nauczanie mogło być efektywne, powinno wyprzedzać rozwój, ponieważ wtedy angażuje cały zakres funkcji leżących w strefie najbliższego rozwoju (Wygotski 1989). W edukacji rozwojowej równie ważną funkcję pełni interakcja między dzieckiem i bardziej kompetentnym od niego partnerem. Mogą być nim dorosły, tutor lub nauczyciel. Interakcja ta jest metaforycznie nazywana budowaniem rusztowania (Wood 1995). Proces ten jest opisywany jako responsywne uczenie się pod kierunkiem i we współpracy z dorosłym. Taką sytuację nazywa się Epizodem Wspólnego Zaangażowania. Przedmiotem działalności dziecka jest w tej sytuacji zadanie, rolą dorosłego zaś stworzenie warunków umożliwiających uczniowi wykonanie tego zadania (Filipiak 2015).

\section{Metoda badań}

Wykorzystanie eksperymentów na zajęciach edukacyjnych z dziećmi miało na celu wprowadzenie uczniów w tematykę tych zajęć. Moim drugim zamierzeniem było poszukiwanie odpowiedzi na następujące pytania badawcze:

1. Czy wykorzystanie eksperymentów będzie miało znaczący wpływ na zaangażowanie uczniów?

2. Czy wykorzystanie eksperymentów pobudzi ciekawość poznawczą dzieci?

3. Czy wprowadzenie dzieci w działalność o charakterze eksperymentatorskim zachęci je do eksploracji i poszukiwania odpowiedzi na wyłaniające się pytania (jeśli takie się pojawią)? 
Ze względu na charakter podejmowanych przeze mnie działań należy je zaliczyć do badań oceniających w odmianie autoewaluacyjnej. Według Krzysztofa Konarzewskiego (2000) badania te mają na celu dostarczenie odpowiednich danych potrzebnych do podjęcia decyzji w sprawie programu czy innowacji. Autor wymienia trzy możliwe sposoby dalszego postępowania: kontynuacja działań, wprowadzenie zmian lub porzucenie. W moim przypadku innowacją było wykorzystanie eksperymentów jako wprowadzenia dzieci w tematykę zajęć oraz zachęcenia ich do dalszej eksploracji zjawisk. Zarówno instrukcje, jak i dyskusja miały służyć jako metaforyczne „rusztowanie”, stwarzając dzieciom odpowiednie warunki do wykonania zadania. Ponadto pracowałam z grupą swoich wychowanków, co pozwoliło mi na pominięcie etapu poznawania dzieci. Trzeba także zaznaczyć, że zajęcia odbywały się w warunkach naturalnych, a ewaluacji poddawałam nie tylko uczniów, ale również własne zachowania. Wszystkie lekcje były nagrywane, a transkrypcje wypowiedzi uczniów zostały później poddane analizie.

\section{Opis eksperymentów}

Eksperymenty koncentrowały się na tematach światła i dźwięku. Wszystkie zajęcia zostały zaprojektowane według schematu przedstawionego na rysunku 1.

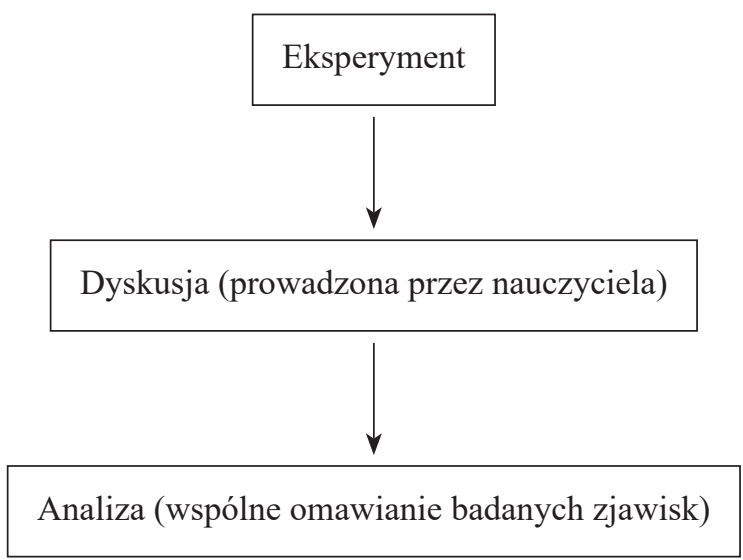

Rysunek 1. Schemat etapów zajęć

Źródło: opracowanie własne.

Czynności badawcze dzieci koncentrowały się w pierwszej kolejności na temacie światła. Podczas zajęć dotyczących tego zagadnienia zostały wykorzystane pudełka z wyciętymi otworami różnej wielkości oraz przedmioty codziennego użytku (klocek, gumka, ołówek, zabawki). Zajęcia przebiegały następująco:

1. ochotnik podchodził i zaglądał do jednego z pudełek z pokrywką;

2. dziecko próbowało zidentyfikować przedmiot znajdujący się wewnątrz; 
3. propozycje zostały zapisane na tablicy;

4. nauczyciel ściągał pokrywkę z pudełka (nie pokazując zawartości);

5. ochotnik ponownie zaglądał do pudełka i próbował nazwać to, co znajdowało się w środku;

6. propozycje ponownie zostały zapisane na tablicy;

7. nauczyciel pokazywał zawartość pudełka;

8. wszystkie dzieci weryfikowały pomysły zapisane na tablicy.
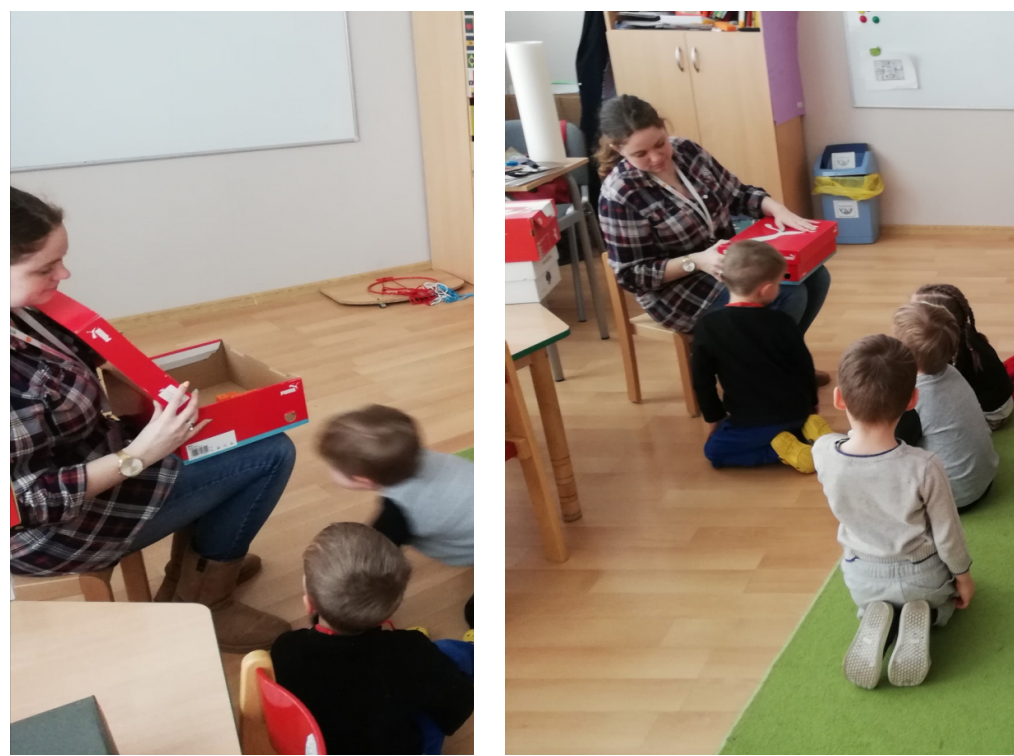

Zdjęcia 1, 2. Eksperyment z pudełkiem

Źródło: archiwum autorki.

Następnie odbywała się dyskusja sprowokowana pytaniami zadawanymi przez nauczyciela („Czy łatwiej było zobaczyć, co jest w pudełku, gdy było otwarte czy gdy było przykryte pokrywką?”, „Dlaczego według was łatwiej zobaczyć coś w odsłoniętym pudełku?"). Pytania te razem z eksperymentem miały za zadanie wprowadzić uczniów w temat zajęć i zachęcić do dalszej eksploracji.

Kolejne zajęcia dotyczyły dźwięku i zostały przeprowadzone w formie pracy grupowej na wydzielonych stanowiskach. Każda ze stacji została wcześniej przygotowana przez nauczyciela, a zajęcia przebiegały w następujący sposób:

1. dzieci zostały podzielone na grupy;

2. nauczyciel wyjaśnił uczniom zasady pracy na zajęciach;

3. nauczyciel pokazał każde stanowisko (zadawał uczniom pytania dotyczące przedmiotów znajdujących się na każdym stoliku i tego, co ich zdaniem należy zrobić);

4. nauczyciel wyjaśnił (nie demonstrował), co należy zrobić na każdym stanowisku; 
5. nauczyciel wskazał każdej grupie stację początkową i dał sygnał do rozpoczęcia pracy;

6. uczniowie eksperymentowali przy każdym stanowisku, a następnie siadali na dywanie (opis stanowisk znajduje się w tab. 1).

Kolejnym etapem zajęć była dyskusja ukierunkowywana pytaniami zadawanymi przez nauczyciela („Co robiliście na stanowisku nr 1?”, „Co się działo?”, „Jak myślicie, dlaczego tak się stało?”). Pytania pełniły funkcję pomocniczą, ich celem było bowiem wprowadzenie dzieci do tematu zajęć oraz ukierunkowanie dalszych poszukiwań dzieci w tym zakresie.

Tabela 1. Opis eksperymentów z dźwiękiem

\begin{tabular}{|l|l|}
\hline \multicolumn{1}{|c|}{ Nazwa } & \multicolumn{1}{c|}{ Opis } \\
\hline wibrujące linijki & $\begin{array}{l}\text { Do stołu przyklejamy dwie linijki różnej długości. Dzieci wprawiają je } \\
\text { w wibracje, słuchają dźwięku, jaki wydają i szukają między nimi różnic }\end{array}$ \\
\hline skacząca posypka & $\begin{array}{l}\text { Na stole stawiamy miskę, którą zakrywamy przezroczystą folią. Na } \\
\text { wierzch kładziemy posypkę. Nachylamy się nad miską i wydajemy } \\
\text { z siebie dźwięk nucenia (bez otwierania ust), a następnie obserwujemy, } \\
\text { jak posypka skacze }\end{array}$ \\
\hline siła dźwięku & $\begin{array}{l}\text { Na stole stawiamy zapaloną świeczkę. Bierzemy rolkę po papierze } \\
\text { toaletowym i zaklejamy ją z obu stron, dodatkowo z jednej robimy } \\
\text { małą dziurkę. Następnie ustawiamy rolkę nad świeczką i uderzamy } \\
\text { w jedną z zaklejonych stron (tę bez otworu) i obserwujemy, jak dźwięk } \\
\text { zdmuchuje płomień }\end{array}$ \\
\hline śpiewający widelec & $\begin{array}{l}\text { Bierzemy kawałek sznurka i składamy go na pół. Na środku } \\
\text { przywiązujemy widelec. Następnie przykładamy końce sznurka do uszu, } \\
\text { uderzamy czymś metalowym w widelec i słuchamy, jak śpiewa }\end{array}$ \\
\hline
\end{tabular}

Źródło: opracowanie własne.

Opisane w tabeli 1 zajęcia zakończono analizą badanych zjawisk. Dzieci dokładnie omawiały to, co się wydarzyło podczas eksperymentu, i próbowały wyjaśnić, co było tego powodem. Nauczyciel pomagał, systematyzując wiedzę dzieci. W obu zajęciach dzieci mogły w części wprowadzającej samodzielnie odkrywać zjawiska, następnie rozmawiały o nich z udziałem nauczyciela, a pod koniec zajęć formułowały temat zajęć oraz wnioski dotyczące badanych zjawisk.

\section{Zgromadzone obserwacje}

W tej części artykułu zostały omówione kategorie opisu, które pojawiły się w zapisie wypowiedzi dzieci. W transkrypcji zajęć można znaleźć takie sformułowania, jak: „fajne”, ,super”, „,́mieszne” i „ekstra”. Wszystkie te określenia wskazują, że eksperymenty rozbudziły zainteresowanie uczniów: 
Ale to fajne ... łoooo...

... no i wtedy te kulki tak fajnie tańczyły i to było ekstra.

No bo te linijki tak skakały, jakby... i wtedy taki dźwięk był i to było takie śmieszne.

O jaaa... ale super.

Wypowiedzi wskazują na to, że taka forma zajęć była dla dzieci czymś nowym, dzięki czemu podchodziły do zajęć z większym entuzjazmem. Wynika z tego także to, że postawienie uczniów w nowej sytuacji, znacząco różniącej się od codziennych praktyk, zasadniczo wpłynęło na poziom ich zaangażowania w zajęcia.

O rozbudzeniu ciekawości dzieci i ich dużej aktywności świadczą wypowiedzi dzieci, w których widoczna jest chęć częstszego uczestniczenia w takiej formie zajęć:

Nam chyba wyszło, eee, bo jak walnąłem, to ta świeczka zgasła, a o to chyba chodziło, ale chciałbym więcej takich ćwiczeń.

Dla mnie to takie zadania mogą być codziennie.

A możemy takie eksperymenty robić częściej? Nooo, bo ja je bardzo lubię.

Przywołane wypowiedzi wskazują na to, że forma pracy, w której uczniowie przejmują inicjatywę, mogą samodzielnie odkrywać i zdobywać wiedzę, jest dla nich bardzo atrakcyjna. Dzieci nie mogły się doczekać na swoją kolej, co również może świadczyć o tym, jak bardzo były przejęte działaniem i chętne do pracy na zajęciach.

Teraz ja, noo już.

Moja kolej teraz.

Oooo, a teraz ja w końcu.

Ja chcę.

Mnie pani wybierze, nooo prooooszę.

Analizując wypowiedzi uczniów, można dojść do wniosku, że wprowadzenie eksperymentów jako formy pracy znacząco zwiększa ich zaangażowanie, ponieważ jest dla nich czymś nowym i ciekawym. Ponadto pozwala im na swobodne badanie zjawisk i konstruowanie wiedzy.

W transkrypcji zajęć są także sformułowania świadczące o tym, że dzieci same organizowały swoją pracę (zwłaszcza podczas lekcji dotyczącej dźwięku). Przykładem mogą być następujące wypowiedzi:

Ja będę pierwszy, a po mnie Julek, a potem ty, dobra?

Jak ja skończę, to wtedy będzie twoja kolej.

Dobra, to ja będę grał na pierwszej linijce, a ty na drugiej wtedy, a Larysa na trzeciej, żeby każdy miał swoją.

To jak to miało być, ehh, mieliśmy to uderzyć chyba w no, to wtedy może ja uderzę, a ty będziesz trzymać, OK? 
Można zatem zauważyć, że uczniowie sami potrafili zorganizować swoją pracę w grupie i rozdzielić zadania, dbali także o to, by każdy miał szansę na wzięcie udziału w eksperymencie.

Niezwykle istotną kwestią, która pojawiła się w czasie zajęć, była możliwość stawiania hipotez przez dzieci. Jest to widoczne zarówno podczas lekcji o świetle, jak i o dźwięku. Uczniowie zadawali pytania, czego przykładem są przytoczone wypowiedzi:

A ciekawe, co się stanie, jak walnę w widelec i złapię za sznurek?

Aaa, jak będę głośniej mruczeć, to posypka będzie mocniej tańczyć czy nie?

A jak zatkam tę dziurkę, to świeczka i tak zgaśnie?

Uczniowie nie poprzestali na stawianiu hipotez. Każde z założeń zostało przez nich zweryfikowane, o czym świadczą następujące wypowiedzi:

Jaaa, jak złapię za sznurek, to tak nie słychać już.

Chyba nie tańczy mocniej, jak jestem głośniej, ta posypka... a myślałem, że będzie.

Ha, i widzisz, mówiłem, że jak zatkasz, to już nie dasz rady zgasić świeczki, bo dźwięk nie ma jak uciekać.

Eksperymenty nie tylko pobudziły ciekawość poznawczą uczniów, ale jednocześnie stworzyły odpowiednie warunki do eksploracji i poszukiwania odpowiedzi na pojawiające się pytania. Uczniowie mogli, a co ważniejsze, sami mieli potrzebę dogłębnego badania zjawisk poprzez stawianie i weryfikowanie hipotez. Sam eksperyment zachęcił ich do dalszych działań. Ponadto wiedza zdobyta w sposób praktyczny i samodzielny zapewne będzie trwalsza.

\section{Dyskusja}

Edukacja przyrodnicza jest niezwykle ważna na etapie edukacji wczesnoszkolnej. Pozwala uczniom odkrywać środowisko, w którym żyją, zjawiska naturalne, a także sprawdzać nowe pomysły (Özbey, Alisinanoğlu 2008). Dzieci w tym wieku są bardzo aktywne i uczą się najlepiej wówczas, kiedy mogą czegoś samodzielnie doświadczyć (French 1996). Uczniowie na etapie edukacji wczesnoszkolnej powinni być zaangażowani w eksplorowanie zjawisk, zarówno w klasie, jak i poza nią. Działania te powinny zawierać element zabawy, być ekscytujące i umożliwiać prowadzenie dalszych poszukiwań (Mirzaie i in. 2009). Rasol Mirzaie, Farideh Hamidi i Ashraf Anaraki (2009) w swoich badaniach koncentrują na związku między aktywnością badawczą a kreatywnością dzieci w wieku przedszkolnym. Autorzy twierdza, że zaangażowanie dzieci w aktywność o charakterze praktycznym w zakresie edukacji przyrodniczej zwiększa ich kreatywność. Powadzenie eksperymentów pozwala nauczycielowi na wykorzystanie naturalnej ciekawości poznawczej i aktywności dzieci, co sprzyja optymalnemu uczeniu się dzieci. Należy także zaznaczyć, że wszelkiego rodzaju aktywność o charakterze eksperymentatorskim daje na- 
uczycielowi możliwość aktywizowania uczniów w procesie kształcenia, pozwalającego na podniesienie efektywności procesu nauczania i uczenia się. Niezwykle istotne jest to, by dzieci w wieku wczesnoszkolnym mogły aktywnie uczestniczyć w procesie kształcenia i zdobywać takie umiejętności, jak praca w grupie, stawianie i weryfikowanie hipotez oraz wyciąganie wniosków.

Zgromadzone obserwacje pozwalają na stwierdzenie, że eksperymentowanie służy rozbudzaniu zainteresowań dzieci, ich zaangażowania oraz ciekawości poznawczej. Wprowadzenie dzieci w działalność o charakterze eksperymentatorskim zachęca je do eksplorowania i poszukiwania odpowiedzi na wyłaniające się pytania. Zadania przygotowane na lekcjach pobudziły ciekawość uczniów, wprowadziły je w temat zajęć i jednocześnie ukierunkowywały dalsze poszukiwania dzieci w danym zakresie. Warto również zaznaczyć, że chociaż eksperyment wymaga ścisłego przestrzegania procedury badawczej, nadal jednak może pobudzać do stawiania pytań oraz eksplorowania. Wyraźnie widać zatem, jak wiele możliwości stwarza wykorzystanie eksperymentu na zajęciach z dziećmi na tym etapie edukacyjnym. Należy pamiętać, że badania te były badaniami autoewaluacyjnymi, które są obciążone samopotwierdzaniem się przyjętych wcześniej założeń, a także subiektywnością wyników, co oznacza, że należy do nich podchodzić z pewną ostrożnością.

\section{Literatura}

Atroszko B. (2018), Konstruktywizm jako źródło inspiracji dla rozwoju współczesnej edukacji nauczycieli. W: Reviewed Proceedings of the Interdisciplinary Scientific International Conference for PhD students and assistants. „QUAERE”, 3, 27-29 June.

Bächtold M. (2013), What do students ,,construct” according to constructivism in science education. „Research in Science Education”, 43(6).

Bruner J.S. (1978), Poza dostarczane informacje: Studia z psychologii poznawania. Warszawa, PWN.

Dylak S. (2000), Konstruktywizm jako obiecujaca perspektywa ksztatcenia nauczycieli. W: H. Kwiatkowska, T. Leowicki, S. Dylak (red.), Współczesność a kształcenie nauczycieli. Warszawa, Wyższa Szkoła Pedagogiczna Związku Nauczycielstwa Polskiego.

Filipiak E. (2015), Budowanie rusztowania dla myślenia uczenia się dzieci w perspektywie społeczno-kulturowej teorii Lwa S. Wygotskiego. W: E. Filipiak (red.), Nauczanie rozwijajace we wczesnej edukacji wedtug Lwa S. Wygotskiego. Od teorii do zmiany w praktyce. Bydgoszcz, Agencja Reklamowo-Wydawnicza ArtStudio.

French L.A. (1996), I told you all about it, so don't tell me you don't know: Two-year-olds and learning through language. "Young Children”, 51(2).

Jenkins E.W. (2000), Constructivism in School Science Education: Powerful Model or the Most Dangerous Intellectual Tendency? „Science \& Education”, 9.

Klus-Stańska D. (2000), Konstruowanie wiedzy w szkole. Olsztyn, Wydawnictwo Uniwersytetu Warmińsko-Mazurskiego.

Klus-Stańska D. (2010), Dydaktyka wobec chaosu pojęć i zdarzeń. Wydawnictwo Akademickie „Żak”. Konarzewski K. (2000), Jak uprawiać badania oświatowe. Metodologia praktyczna. Warszawa, Wydawnictwa Szkolne i Pedagogiczne S.A. 
Marek E. (2015), Konstruktywizm determinantem indywidualizacji pracy nauczyciela z uczniem (na podstawie analizy wybranych programów edukacji wczesnoszkolnej). Kraków, Wydawnictwo LIBRON - Filip Lohner.

Mirzaie R.A., Hamidi F., Anaraki A. (2009), A Study on the Effect of Science Activities on Fostering Creativity in Preschool Children. „Journal of Turkish Science Education”, 6(3).

Özbey S., Alisinanoğlu F. (2008), Identifying the General Ideas, Attitudes and Expectations Pertaining to Science Activities of the Teachers Employed in Preschool Education. „Journal of Turkish Science Education", 5(2).

Piaget J. (1966), Narodziny inteligencji dziecka. Warszawa, PWN.

Rybska E. (2017), Przyroda w osobistych koncepcjach dziecięcych - implikacje dla jej nauczania z wykorzystaniem rysunku. Poznań, Wydawnictwo Kontekst.

Szydłowski H. (1991), Nauczanie fizyki a wiedza potoczna uczniów. Poznań, Uniwersytet im. Adama Mickiewicza.

Wendland M. (2011), Perspektywa konstruktywistyczna jako filozoficzna podstawa do rozważań nad edukacją. „Kultura i Edukacja”, 4(83).

Wood D. (1995), Społeczne interakcje jako tutoring. W: A. Brzezińska, G. Lutomski, B. Smykowski (red.), Dziecko wśród rówieśników i dorostych. Poznań, Zysk i S-ka.

Wygotski L.S. (1971), Wybrane prace psychologiczne. Wybór i tłum. E. Flesznerowa i J. Fleszner, red. nauk. E. Franus. Warszawa, PWN.

Wygotski L.S. (1978), Interaction Between Learning and Development. W: M. Gauvain, M. Cole (eds.), Readings on the Development of Children. New York, Scientific American Books.

Wygotski L.S. (1989), Myślenie i mowa. Tłum. E. Flesznerowa i J. Fleszner. Warszawa, PWN. 